\title{
EFFECT OF SOME FERTILIZATION TREATMENTS AND SPRAYING GARLIC EXTRACT ON GROWTH AND FLOWERING OF HEDYCHIUM CORONRIUM PLANTS
}

\author{
Eman A. Attia(1), S.A.A. Gomaa(1) and M.A. Hegazi ${ }^{(2)}$ \\ (1) Ornamental plants and landscape gardening Res. Dept., Hort. Res. Inst., ARC,Egypt. \\ ${ }^{(2)}$ Hort. Dept., Fac. Agric., Kafr El-Shiekh Univ.
}

Received: Nov. 17, 2020

Accepted: Nov. 25, 2020

\begin{abstract}
A pot experiment was conducted to study the effect of three rates of krestalon compound fertilizer NPK (19:19:19) as 2, 4 and 6g/pot, garlic extract at 25, 50 and $100 \%$ and their combinations on growth, flowering and chemical constituents of Hedychium plants. Results showed that, NPK fertilizer at either 4 or $6 \mathrm{~g} / \mathrm{pot}$ with $50 \%$ garlic extract enhanced vegetative growth parameters in terms of plant height, shoot number/clump, number of leaves/main shoot and leaf area in both seasons. Besides, the highest values of fresh and dry weights of root and main shoot as well as the highest carbohydrate, $\mathrm{N}, \mathrm{P}$ and $\mathrm{K} \%$ were recorded in plant leaves fertilized with 4 or $6 \mathrm{~g} /$ pot and sprayed with $50 \%$ garlic extract in both seasons. In addition, the highest flowering parameters such as main stalk length, main stalk diameter, inflorescence number/clump, rachis length, florets number/inflorescence, flowering spike fresh and dry weight were obtained from plants treated with 4 or $6 \mathrm{~g} /$ pot NPK and sprayed with 50 or $100 \%$ garlic extract in both seasons. Also, the treatment of 4 or $6 \mathrm{~g} /$ pot NPK and spraying with 50 or $100 \%$ gave the best vase life (days) and showed to be the superior one to induce earlier flowering as compared to control and other treatments. Therefore, it could be recommended that fertilizing Hedychium plants with compound fertilizer of NPK $(19: 19: 19)$ at $4 \mathrm{~g} /$ pot and spraying with garlic extract at $50 \%$ is considered the best and economic treatment used for enhancing growth, flowering and improving the nutritional status of the plant.
\end{abstract}

Key words: Hedychium, plant extracts, flowering, growth, nutritional status

\section{INTRODUCTION}

Hedychiums are medium-sized rhizomatous perennial monocotyledon plants belongs to Family Zingiberaceae which can be easily recognized by their characteristic striking foliage and terminal spikes that produce diversified numerous flamboyant flowers with several hues and fragrances varying depending on the species (Ashokan and Gowda , 2018). These features give them a high ornamental value, being cultivated worldwide mostly for this purpose and for its use in the perfumery industry, since, besides the aromatic flowers; Hedychium species rhizomes also originate strongly scented oils (Chan and
Wong 2015 \& Yue et al., 2015). Fertilization and natural plant extracts are among the important agricultural treatments which have been proven to improve growth, flowering and bulbs and seeds production of ornamental plants (Ahmad et al., 2014; Hassan et al., 2015 and EI-Mahrouk et al., 2016). The effect of fertilization on enhancing nutritional status, growth development and flower production of ornamental plants were reported by many investigators (Ruamrungsri et al., 2011; El-Naggar 2010; Youssef 2014; El-Naggar and ElNasharty 2016; Al-Ajlouni et al., 2017; Abd El-Gayed and Attia 2018; Gaber, 2019 \& Altaee and Alsawaf 2020). In this 
respect, Bashir et al., (2016) on Gladiolus grandiflorus found that application of $\mathrm{N}$, $P$ and $K$ in different combinations had $a$ remarkable effect on most vegetative growth, flowering and nutritional status as the optimal rate was $10: 20: 10 \mathrm{~g} \mathrm{~m}^{2}$ of NPK for plant height, leaf area, pike length, floret diameter, floret fresh and dry weight as well as leaf chlorophyll content, NPK uptake and number of cormels per clump. Moreover, they suggested that in order to attain sustainable production of Gladiolus grandiflorus, balanced fertilization is necessary and optimum use of compound fertilizer would help better towards vigorous growth and maximum flower production. Also, El-Mokadem and Sorour (2014) reported that Petunia hybrida fertilized with $5 \mathrm{~g} /$ pot complete fertilizer of NPK (19:19:19) gave the best growth parameters in terms of plant height, number of branches and leaf area as well as dry weight of shoots and roots. Moreover, Habib (2012) revealed that Caryota seedlings fertilized with $4 \mathrm{gm} /$ pot NPK gave the highest values of chlorophyll a, b and total carbohydrates in the leaves.

The use of extracts of certain plants as bio stimulants for plants such as garlic extract in improving the growth of agriculture crops especially ornamental plants is highly recommended as an environment friendly and safe approach to get better plants without being forced to use chemical nutrients or synthetic growth regulators that may harm the environment. El-Bably (2017) on Polianthes tuberosa reported that spraying garlic extract at $9 \mathrm{ml} / \mathrm{l}$ increased leaf length, number of leaves and induced precocity in flowering, increased spike and rachis length, number of florets per spike, fresh weight of florets, fresh and dry weights of spike. Also, it significantly increased number of bulblets, fresh weight of clump, fresh weight of new formed bulb and its diameter as well as increased chlorophyll, carbohydrates content and NPK percentages in the leaves. Also, ALKaisy et al., (2013) revealed that spraying garlic extract and on ginger seeds increased in many characteristics: plant height, leaf chlorophyll and carbohydrates content, relative growth rate, absolute growth rate and seed yield. Emam (2010), on Polianthes tuberosa reported that garlic extract at 1 and $5 \mathrm{ml} / \mathrm{l}$ improved flowers traits, increased clump fresh weight, clump dry weight, number of bulbs/plant and number of bulblets/plant. Atowa (2012) on Freesia refracta found that application of garlic extract at $500 \mathrm{ml} / \mathrm{l}$ increased number and fresh weight of cormlets and chlorophyll (a), whereas using garlic extract at 250 $\mathrm{ml}$ /l significantly increased total carbohydrates, $\mathbf{N}, \mathrm{P}$ and $\mathrm{K}$ contents in the leaves. Hanafy et al., (2012) on Schefflera arboricola plants stated that the highest values of plant height, dry weight of leaves/plant, total carbohydrates and nitrogen contents were obtained when using garlic extract as a soil drench compared with foliar spray method. ELSayed et al., (2015) on Freesia refracta reported that using garlic extract at $\mathbf{5 0 0}$ $\mathrm{ml} / \mathrm{l}$ increased number of cormlets/plot, fresh weight of cormlets and chlorophyll (a) in the leaves as well as a great influence was detected on carbohydrates content due to applying garlic extract.

Therefore, the present study was conducted to evaluate the effect of krestalon compound fertilizer as a source of NPK, spraying garlic extract and their combination on growth and flowering of Hedychium plants.

\section{MATERIALS AND METHODS}

A pot experiment was carried out at Sakha Horticulture Research Station, Kafr El Sheikh Governorate Egypt during 2017 and 2018 seasons to study the effect of three rates of the compound 
Kristalon fertilizer (19:19:19 NPK) and spraying with three levels of garlic extract and their combinations on growth, flowering and rhizome production of Hedychium plants. Hedychium coronarium local cultivar rhizome was obtained from Horticulture Research Institute, Giza, Egypt. Average rhizome weight was $20-30 \mathrm{~g}$, length $10-$ $15 \mathrm{~cm}$ and diameter $4-5 \mathrm{~cm}$ for the first and second seasons, respectively. Rhizomes were planted on March $21^{\text {st }}$ for both seasons in clay pots of $30 \mathrm{~cm}$ diameter containing a mixture of sand and clay $(1: 2 \mathrm{v} / \mathrm{v})$. Soil samples before treatments and samples from garlic extract used in this study were taken for chemical analysis and minerals content according to Page et al., (1982) and ElBably (2017); and data are shown in Table (1). The plants received the common agricultural practices such irrigation, manual weed control, etc. were carried out when needed. After four weeks from planting date and plants arrived to $10 \mathrm{~cm}$ in length, the plants were subjected to the following treatments.
- Control

- Fertilizing with kristalon at $2 \mathrm{~g} /$ pot

- Fertilizing with kristalon at $4 \mathrm{~g} /$ pot

- Fertilizing with kristalon at $6 \mathrm{~g} / \mathrm{pot}$

- Spraying with garlic extract at $25 \%$

- Spraying with garlic extract at $50 \%$

- Spraying with garlic extract at $100 \%$

- Fertilizing with kristalon at $2 \mathrm{~g} /$ pot + spraying with garlic extract at $25 \%$

- Fertilizing with kristalon at $2 \mathrm{~g} /$ pot + spraying with garlic extract at $50 \%$

- Fertilizing with kristalon at $2 \mathrm{~g} /$ pot + spraying with garlic extract at $100 \%$

- Fertilizing with kristalon at $4 \mathrm{~g} /$ pot + spraying with garlic extract at $25 \%$

- Fertilizing with kristalon at $4 \mathrm{~g} /$ pot + spraying with garlic extract at $50 \%$

- Fertilizing with kristalon at $4 \mathrm{~g} /$ pot + spraying with garlic extract at $100 \%$

- Fertilizing with kristalon at $6 \mathrm{~g} /$ pot + spraying with garlic extract at $25 \%$

- Fertilizing with kristalon at $6 \mathrm{~g} /$ pot + spraying with garlic extract at $50 \%$

- Fertilizing with kristalon at $6 \mathrm{~g} /$ pot + spraying with garlic extract at $100 \%$

Table (1): Physical and Chemical analysis and mineral content of soil and garlic extract.

\begin{tabular}{|c|c|c|c|}
\hline \multicolumn{2}{|l|}{ Soil analysis } & \multicolumn{2}{|c|}{ Garlic extract analysis } \\
\hline parameters & Value & Parameters & Value \\
\hline Clay & 36.2 & Lysine & $0.273 \mathrm{~g}$ \\
\hline Silt & 23.4 & Carbohydrates & $33.07 \mathrm{~g}$ \\
\hline Finesand & 14 & Lipids & $0.50 \mathrm{~g}$ \\
\hline Cross sand & 27.3 & Sodium & $17.00 \mathrm{~g}$ \\
\hline Texture sand clay loom & & Magnesium & $32.0 \mathrm{~g}$ \\
\hline pH 1:2.5 & 8.4 & Calories & $149.00 \mathrm{kca}$ \\
\hline $\mathrm{EC} \mathrm{dSm}^{-1} 1: 5$ & 4.16 & Fiber & $2.10 \mathrm{~g}$ \\
\hline $\mathrm{K}^{+} \mathrm{meq} / \mathrm{l}$ & 0.4 & Glutamic acid & $0.805 \mathrm{~g}$ \\
\hline $\mathrm{Ca}^{++} \mathrm{meq} / \mathrm{l}$ & 11.74 & Argenine & $0.634 \mathrm{~g}$ \\
\hline $\mathrm{Mg}^{++} \mathrm{meq} / \mathrm{l}$ & 5.27 & Water & $59 \mathrm{~g}$ \\
\hline $\mathrm{Na}^{+} \mathrm{meq} / \mathrm{l}$ & 23.14 & Aspartic acid & $0.489 \mathrm{~g}$ \\
\hline $\mathrm{HCO}_{3}^{-} \mathrm{meq} / \mathrm{l}$ & 5.79 & Leucine & $0.308 \mathrm{~g}$ \\
\hline $\mathrm{Cl}^{-} \mathrm{meq} / \mathrm{l}$ & 14.98 & Manganese & $1672.00 \mathrm{mg}$ \\
\hline $\mathrm{SO}_{4}^{--} \mathrm{meq} / \mathrm{l}$ & 19.84 & Valcum & $181.00 \mathrm{mg}$ \\
\hline $\mathrm{CO}_{3}^{-}$ & 0 & Phosphorus & $153.00 \mathrm{mg}$ \\
\hline Total N, \% & 23.2 & Potassium & $401.00 \mathrm{mg}$ \\
\hline Available $P, \mathrm{mg} / \mathrm{kg}$ soil & 8.3 & Sulphur & $70.00 \mathrm{mg}$ \\
\hline Available $\mathrm{K}, \mathrm{mg} / \mathrm{kg}$ soil & 51.9 & Vit.B6 & $1235.00 \mathrm{mg}$ \\
\hline
\end{tabular}




\begin{tabular}{|l|l|c|}
\hline & & Vitamin c \\
fiber & $31.00 \mathrm{mg}$ \\
& & $2.10 \mathrm{~g}$ \\
\hline
\end{tabular}

One hundred and ninety two plants were selected uniformly and arranged in a randomized complete block design with three replicate, each replicate contained four plants. Kristalon as compound fertilizer NPK (19:19:19) was applied via soil at three rates i.e. 2,4 and $6 \mathrm{~g} /$ pot in four doses, the first dose was applied after two months from planting date, the second dose was applied after two months from first dose, the third dose was applied after two months from the second dose and the fourth was applied after cut flowering spikes. One $\mathrm{kg}$ fresh mature garlic cloves were blended in the presence of distilled water $(1 \mathrm{~kg} / \mathrm{l})$, then frozen (24 hours) and thawed two times then filtered according to El-Desouky et al. (1998). The size of filtering extract was $300 \mathrm{ml}$ represented $100 \%$ concentration, then $150 \mathrm{ml}$ was taken from the same filtering extract and added water to complete $300 \mathrm{ml}$ with $50 \%$ concentration. Also, $75 \mathrm{ml}$ was taken from the same filtered extract and added water to complete $300 \mathrm{ml}$ with $25 \%$ concentration. Foliar application of garlic extract at 100,50 and $25 \%$ was done after four weeks from planting date at 15 days intervals at early morning.

\section{The following data was recorded:}

\section{Vegetative growth:}

Plant height (cm), total shoot number/clump, leaf number/main shoot, leaf area $\left(\mathrm{cm}^{2}\right)$, and main shoot fresh and dry weight, per plant(g)as well as root fresh and dry weights per plant $(g)$.

\section{Some chemical constituents in the leaves:}

Twenty mature leaves were sampled from each treatment and dried at $70^{\circ} \mathrm{C}$ to a constant weight, and then $0.5 \mathrm{~g}$ powder from dried leaves was taken to determine total carbohydrates according to Doubis et al., (1956). Dried leaves were ground and digested with $\mathrm{H}_{2} \mathrm{SO}_{4}$ and $\mathrm{H}_{2} \mathrm{O}_{2}$ according the method described by Evenhuis and Dewaard (1980) to determine the elements of $\mathrm{N}, \mathrm{P}$ and $\mathrm{K}$. Total nitrogen \% was determined by using the micro-Kjeldahle method as described by Pregl (1945), phosphorus \% was determined coloremetrically as described by Murphy and Riley (1962), potassium \% was estimated by using flame photometer as described by Brown and Lillelland (1974).

\section{Flowering parameters:}

Flowering characters: flowering date (days), main stalk length (cm), main stalk diameter (cm), inflorescence number/clump, rachis length $(\mathrm{cm})$, florets number/ inflorescence, fresh and dry weights of flowering spike (g) and vase life (days).

\section{Statistical analysis:}

Statistical analysis was done as analysis of variance according to Snedecor and Cochran (1990) and the differences among treatment means were compared by the least significant differences (LSD at $5 \%$ level),

\section{RESULTS AND DISCUSSION}

\section{Vegetative growth characters:}

\subsection{Growth parameters:}

Data presented in Table (2) showed that NPK fertilization and garlic extract foliar spray, alone or combined significantly increased plant height, shoot number/clump, number of leaves/main shoot and leaves area of Hedychium plants compared to control treatment. Fertilization with NPK and garlic extract as individual application increased all growth parameters 
compared with control. It is also clear that NPK fertilization treatments proved better compared to garlic extract concentrations and control. The highest values of plant height, shoot number/clump, number of leaves/main shoot and leaves area were obtained from plants treated with $6 \mathrm{gm} \mathrm{NPK}+50 \%$ garlic extract followed by 4 gm NPK + $50 \%$ garlic extract without significant differences in between them in both seasons. On the other hand, the lowest values of growth parameters belonged to control treatment in both seasons. These findings are in line with those obtained by Abd El-Gayed and Attia (2018) they found that adding compound fertilizer $\operatorname{NPK}(20: 20: 20)$ at rates of $0,1.5,3$ and 4.5 $\mathrm{g} /$ pot on cocks comb (Celosia argentea) plants increased number of leaves and branches/plant. In this respect, Youssef (2014) concluded that raising chemical fertilizer of NPK (19:19:19) rates from 0.0 to $6.0 \mathrm{~g} /$ pot have high positive effect and significantly improved plant height and leaf number/plant of ponytail palm plants. Similarly, Hanafy et al., (2012) reported that application of garlic extract at $250 \mathrm{~g} / \mathrm{l}$ on Schefflera arboricola plants markedly increased plant height, number of leaves/plant and leaf area as compared to yeast extract, aloe extract and henna extract. Also, Abdulrazzaq (2017) revealed that spraying Gazania splendes plants with $2 \mathrm{ml}$ garlic extract per liter caused highest increase in plant height, leaf number/plant and leaf area compared to licorice root extract. Our results about combined effect among fertilizer rates and garlic extract levels are in agreement with those of Abdou et al., (2018a). In this respect, Abdou et al., (2018) reported that adding compost fertilizers at7.5 ton/feddan and spraying with garlic extract at $300 \mathrm{mg} / \mathrm{l}$ significantly enhanced the most vegetative growth parameters of Gladiolus grandiflorus plants. Also, Massoud et al., (2017) indicated that the highest values of plant height and number of branches/ plant of marjoram plants were produced with using biogene plus phosphorene as biofertilizers in combination with active dry yeast or garlic extract treatments compared with control.

Table (2): Effect of NPK fertilization and spraying garlic extract on some growth parameters of Hedychium coronerium plants during 2017 and 2018 seasons

\begin{tabular}{|l|c|c|c|c|c|c|c|c|}
\hline \multirow{2}{*}{ Treatments } & \multicolumn{2}{|c|}{$\begin{array}{c}\text { Plant height } \\
(\mathbf{c m})\end{array}$} & \multicolumn{2}{c|}{$\begin{array}{c}\text { Total shoot } \\
\text { number/clump }\end{array}$} & $\begin{array}{c}\text { Leaf } \\
\text { number/main } \\
\text { shoot }\end{array}$ & \multicolumn{2}{c|}{$\begin{array}{c}\text { leaf area } \\
\left(\mathrm{cm}^{2}\right)\end{array}$} \\
\cline { 2 - 9 } & 2017 & 2018 & 2017 & 2018 & 2017 & 2018 & 2017 & 2018 \\
\hline Control & 63.33 & 64.00 & 8.33 & 8.33 & 8.33 & 7.67 & 29.67 & 30.11 \\
Kristalon 2 g & 69.67 & 71.33 & 9.33 & 11.00 & 9.00 & 8.67 & 31.87 & 32.21 \\
Kristalon 4 g & 78.00 & 79.67 & 12.67 & 13.00 & 11.00 & 11.67 & 38.49 & 40.16 \\
Kristalon 6 g & 74.67 & 76.33 & 10.33 & 12.00 & 9.67 & 10.00 & 31.29 & 33.98 \\
Garlic 25\% & 73.07 & 77.00 & 8.67 & 10.67 & 12.00 & 12.67 & 39.85 & 41.84 \\
Garlic 50\% & 69.00 & 72.33 & 13.00 & 13.67 & 9.67 & 10.33 & 43.59 & 45.95 \\
Garlic 100\% & 71.00 & 74.00 & 9.67 & 11.00 & 11.33 & 11.67 & 40.82 & 42.87 \\
K 2 g + G 25\% & 72.33 & 74.67 & 11.00 & 12.33 & 9.33 & 10.00 & 44.88 & 47.23 \\
K 2 g + G 50\% & 78.33 & 81.33 & 12.00 & 14.00 & 10.67 & 13.33 & 47.23 & 51.53 \\
K 2 g + G 100\% & 72.00 & 74.33 & 11.67 & 12.33 & 9.33 & 9.67 & 40.63 & 42.27 \\
K 4 g + G 25\% & 80.33 & 81.67 & 12.33 & 12.67 & 10.00 & 10.67 & 49.26 & 52.93 \\
K 4 g + G 50\% & 85.33 & 84.67 & 13.00 & 14.33 & 12.33 & 13.00 & 48.36 & 50.18 \\
K 4 g + G 100\% & 81.67 & 82.00 & 13.00 & 13.33 & 10.33 & 11.33 & 43.58 & 49.20 \\
K 6 g + G 25\% & 77.67 & 83.67 & 11.67 & 13.00 & 11.33 & 12.33 & 50.27 & 53.08 \\
K 6 g + G 50\% & 85.33 & 87.33 & 13.33 & 14.00 & 12.67 & 14.00 & 46.11 & 48.66 \\
\hline
\end{tabular}




\begin{tabular}{|c|c|c|c|c|c|c|c|c|}
\hline K $6 \mathrm{~g}+\mathrm{G} 100 \%$ & 80.67 & 84.67 & 11.33 & 12.67 & 11.33 & 12.00 & 44.82 & 50.56 \\
\hline F test & ** & ** & ** & ** & ** & ** & ** & ** \\
\hline LSD 0.05 & 5.45 & 5.56 & 2.26 & 2.46 & 1.44 & 1.70 & 4.18 & 4.39 \\
\hline
\end{tabular}

Generally, data in Table (2) indicated that, NPK fertilization and garlic extract foliar application enhanced most vegetative growth parameters of plants in both seasons. The treatment of $6 \mathrm{gm}$ NPK $+50 \%$ garlic extract or 4 gm NPK + $50 \%$ garlic extract was more effective than other treatments. The obtained increase in vegetative growth parameters as a result of NPK fertilization and garlic extract application may be due to the balance between nutritional status and hormones, resulting in faster cell division and cell elongation; which in turn helped the plant growth and root development, and consequently increased plant growth and size (Gaber, 2019 and Elgohary et al., 2020). Garlic extract is also reported to promote vegetative growth which might be attributed to the presence of phytohormones, amino acids and vitamins as well as macro and micro-nutrients (Dahab et al., 2018).

\subsection{Fresh and dry weights:}

Presented results in Table (3) showed that, fresh and dry weight of root and main shoot were significantly affected by fertilization with NPK (19:19:19) and garlic extract foliar spray alone or combined with the other in both seasons. NPK fertilization and garlic extract foliar application as a single treatments increased fresh and dry weights of root and main shoot of plants as compared to control treatment. Moreover, spraying garlic extract was more effective on increasing fresh and dry weight of root and main shoot than fertilizing with NPK in both seasons. Similar results were obtained by Hassan et al., (2015) and Gaber (2019). In this respect, El-Mokadem and Sorour (2014) reported that Petunia hybrida fertilized with $5 \mathrm{~g} /$ pot complete fertilizer of NPK (19:19:19) gave the best fresh and dry weight of shoots and roots. Also, El-Naggar (2010) found that adding compound fertilizer NPK (19:19:19) at rates of $1.0,2.0$ and $3.0 \mathrm{~g} /$ pot on Narcissus tazetta plants caused a gradual significant increase in fresh and dry weight of leaves. Similarly, Emam (2010), on Polianthes tuberosa reported that garlic extract at 1 and $5 \mathrm{ml} / \mathrm{l}$ increased fresh and dry weight of whole plant. Also, Hanafy et al., (2012) on Schefflera arboricola found that garlic extract at the rate of $250 \mathrm{~g} / \mathrm{l}$ as a foliar spray significantly increased fresh and dry weight of leaves/plant. Similar results were obtained by El-Bably (2017) on tuberose bulbs. A great influence was found between NPK fertilizer and garlic extract foliar application on fresh and dry weights of root and main shoot as shown in Table (3). The highest values occurred in plants fertilized with $6 \mathrm{~g} /$ pot plus spraying garlic extract at $50 \%$ followed by $4 \mathrm{~g} /$ pot plus spraying garlic extract at $50 \%$ in both seasons. In contrary, the lowest values were found in untreated plants (control). These results are in agreement with those obtained by Abdou et al., (2017a) who revealed that, fertilizing guar plants with the medium level of compost at 5.0 ton/feddan and spraying the plants with garlic extract $(300 \mathrm{ppm})$ or green tea extract $(150 \mathrm{ppm})$ gave the highest values for dry weight of leaves/plant. Also, Abdou et al., (2018) showed that, gladiolus plants treated with organic compost and foliar spray with extracts of green tea, moringa leaves, garlic, licorice roots, active dry yeast and seaweed led to improving all vegetative growth parameters, which 
included dry weight of leaves/plant.

Table (3): Effect of NPK fertilization and spraying garlic extract on main shoot and root fresh and dry weight of Hedychium coronerium plants during 2017 and 2018 seasons

\begin{tabular}{|l|c|c|c|c|c|c|c|c|}
\hline \multirow{2}{*}{ Treatments } & \multicolumn{4}{|c|}{ Main shoot weight (g) } & \multicolumn{4}{c|}{ Root weight (g) } \\
\cline { 2 - 8 } & \multicolumn{2}{|c}{ Fresh } & \multicolumn{2}{c|}{ Dry } & \multicolumn{2}{c|}{ Fresh } & \multicolumn{2}{c|}{ Dry } \\
\cline { 2 - 8 } & 2017 & 2018 & 2017 & 2018 & 2017 & 2018 & 2017 & 2018 \\
\hline Control & 160.32 & 164.52 & 24.49 & 27.23 & 522.76 & 387.67 & 84.70 & 69.53 \\
Kristalon 2 g & 199.34 & 211.24 & 31.48 & 33.93 & 593.00 & 586.53 & 92.80 & 84.98 \\
Kristalon 4 g & 205.93 & 214.97 & 36.94 & 41.43 & 655.47 & 719.74 & 94.24 & 87.14 \\
Kristalon 6 g & 200.57 & 212.98 & 34.82 & 37.84 & 748.07 & 792.31 & 95.84 & 90.23 \\
Garlic 25\% & 247.75 & 251.48 & 42.84 & 49.90 & 701.47 & 696.77 & 107.18 & 83.63 \\
Garlic 50\% & 258.84 & 265.86 & 48.83 & 51.50 & 858.17 & 804.10 & 114.83 & 90.50 \\
Garlic 100\% & 244.79 & 256.55 & 40.80 & 44.56 & 988.97 & 831.62 & 121.00 & 91.87 \\
K 2 g + G 25\% & 338.26 & 342.60 & 69.97 & 70.37 & 778.10 & 767.27 & 100.50 & 86.60 \\
K 2 g + G 50\% & 380.27 & 385.30 & 81.57 & 90.63 & 888.20 & 774.30 & 112.00 & 80.93 \\
K 2 g + G 100\% & 237.06 & 241.66 & 37.50 & 41.20 & 899.13 & 836.73 & 119.60 & 113.24 \\
K 4 g + G 25\% & 341.15 & 346.20 & 72.91 & 72.13 & 792.33 & 878.30 & 100.30 & 118.37 \\
K 4 g + G 50\% & 447.55 & 449.20 & 91.58 & 92.18 & 870.93 & 908.33 & 120.83 & 116.48 \\
K 4 g + G 100\% & 339.83 & 345.83 & 69.59 & 73.27 & 970.43 & 932.30 & 120.18 & 114.19 \\
K 6 g + G 25\% & 348.47 & 316.20 & 78.60 & 83.97 & 1115.13 & 938.47 & 110.87 & 110.90 \\
K 6 g + G 50\% & 422.89 & 429.94 & 85.29 & 89.59 & 1123.84 & 1039.53 & 112.20 & 117.30 \\
K 6 g + G 100\% & 308.51 & 312.92 & 63.48 & 73.20 & 1150.73 & 1156.54 & 110.89 & 122.12 \\
\hline F test & $\star *$ & $\star *$ & $\star *$ & $\star \star$ & $\star \star$ & $\star \star$ & $\star *$ & $\star \star$ \\
\hline LSD 0.05 & 57.25 & 62.71 & 9.15 & 6.00 & 127.80 & 87.80 & 10.57 & 10.31 \\
\hline
\end{tabular}

\section{Leaf chemical constituents:}

Presented data in Table (4) indicate that, NPK fertilization and foliar spray with garlic extract as well as their combinations had a pronounced effect on increasing leaf $N, P, K$ and total carbohydrates \% of Hedychium plants as compared to control in both seasons. NPK fertilization and garlic extract foliar application as a single treatment increased leaf $N, P, \quad K$ and total carbohydrates \% of Hedychium plants as compared to control treatment. Moreover, fertilizing with NPK was more effective on increasing leaf total carbohydrates \% than spraying garlic extract in both seasons. Whereas, leaves from plants sprayed with garlic extract at 25 and $\mathbf{5 0} \%$ had higher $\mathbf{N}, \mathbf{P}$ and $\mathrm{K} \%$ than that fertilized with NPK. These findings are in accordance with those of Youssef (2014) and Bashir et al., (2016). In this respect, EI-Mokadem and Sorour (2014) revealed that using NPK fertilizer at rate of $5 \mathrm{~g} /$ pot produced the significantly highest values of leaf $\mathbf{N}, \mathbf{P}$ and $\mathrm{K} \%$ compared with plants without fertilization. These results are similar with those reported by Abd ElGayed and Attia (2018) who revealed that, increasing NPK rate from 0.0 to $4.5 \mathrm{~g} /$ pot significantly enhanced percentages of $\mathrm{N}$, $\mathrm{P}$ and $\mathrm{K}$ in leaves of cocks comb (Celosia 
argentea) plants. Our results about the effect of garlic extract foliar application are in agreement with those of El-Bably (2017) who reported that, spraying garlic extract, yeast and humic acid on tuberose plants led to increase total carbohydrates, $\mathbf{N}, \mathbf{P}$ and $\mathrm{K} \%$ in the leaves compared to control. Moreover, treatment of $6 \mathrm{~g} /$ pot NPK + foliar spray with garlic extract at $50 \%$ recorded the highest total carbohydrates, N, P and K \% in leaves of followed by $4 \mathrm{~g} /$ pot NPK + $50 \%$ garlic extract compared with the other treatments in both seasons. On the other hand, control treatment recorded the lowest total carbohydrates, N, P and $K$ in both seasons. The obtained results are in agreement with those reported by Abdou et al., (2017b) as they concluded that adding compost fertilizers at 5 ton/feddan and spraying with garlic extract at $300 \mathrm{mg} / \mathrm{l}$ increased total carbohydrate, $N, P$ and $K \%$ in the leaves of guar plants compared with other plant extracts (moringa, aloe and green tea).

\section{Flowering parameters:}

Results in Tables $(5 \& 6)$ and Figure (1) showed that, NPK fertilization, foliar spray with garlic extract and their combinations had significant effects on all flowering parameters in terms of flowering date, main stalk length, main stalk diameter, inflorescence number/clump, rachis length, florets number/inflorescence, flowering spike fresh and dry weight and vase life in both seasons. Regarding the effect of NPK fertilization and spraying with garlic extract on flowering date, results illustrated in Figure (1) revealed that NPK fertilization and spraying with garlic extract alone or combined induced earlier flowering of Hedychium plants as compared with control in both seasons. In this respect, plants fertilizing with 4 and $6 \mathrm{~g} / \mathrm{pot}$ and sprayed with garlic extract at $50 \%$ tended to flower earlier than that of the other treatments in both seasons.

Table (4): Effect of NPK fertilization and spraying garlic extract on total carbohydrate and NPK \% in leaves of Hedychium coronerium plants during 2017 and 2018 seasons

\begin{tabular}{|l|c|c|c|c|c|c|c|c|}
\hline \multirow{2}{*}{ Treatments } & \multicolumn{2}{|c|}{$\begin{array}{c}\text { Total } \\
\text { carbohydrate } \\
\%\end{array}$} & \multicolumn{2}{|c|}{ N \% } & \multicolumn{2}{c|}{ P \% } & \multicolumn{2}{c|}{ K \% } \\
\cline { 2 - 9 } & 2017 & 2018 & 2017 & 2018 & 2017 & 2018 & 2017 & 2018 \\
\hline Control & 19.09 & 18.40 & 1.23 & 1.19 & 0.27 & 0.29 & 1.76 & 1.66 \\
Kristalon 2 g & 21.68 & 21.67 & 1.61 & 1.64 & 0.32 & 0.32 & 2.58 & 2.55 \\
Kristalon 4 g & 24.51 & 24.57 & 1.68 & 1.64 & 0.34 & 0.34 & 2.60 & 2.59 \\
Kristalon 6 g & 23.25 & 23.17 & 1.80 & 1.81 & 0.40 & 0.41 & 2.59 & 2.62 \\
Garlic 25\% & 25.72 & 25.13 & 1.83 & 1.81 & 0.43 & 0.45 & 2.54 & 2.46 \\
Garlic 50\% & 27.87 & 29.00 & 1.70 & 1.89 & 0.35 & 0.35 & 2.68 & 1.92 \\
Garlic 100\% & 27.06 & 26.00 & 1.48 & 1.46 & 0.40 & 0.37 & 2.67 & 2.70 \\
K 2 g + G 25\% & 33.41 & 30.90 & 1.74 & 1.72 & 0.43 & 0.48 & 2.58 & 2.52 \\
K 2 g + G 50\% & 38.05 & 37.38 & 1.81 & 1.85 & 0.34 & 0.35 & 2.64 & 2.64 \\
K 2 g + G 100\% & 30.51 & 30.40 & 1.75 & 1.77 & 0.37 & 0.39 & 2.76 & 2.74 \\
K 4 g + G 25\% & 28.59 & 29.03 & 1.79 & 1.83 & 0.42 & 0.44 & 2.73 & 2.75 \\
K 4 g + G 50\% & 35.54 & 35.80 & 1.87 & 1.88 & 0.50 & 0.51 & 2.76 & 2.78 \\
\hline
\end{tabular}


Effect of some fertilization treatments and spraying garlic extract on growth........

\begin{tabular}{|l|c|c|c|c|c|c|c|c|}
\hline K 4 g + G 100\% & 33.66 & 34.53 & 1.80 & 1.83 & 0.45 & 0.47 & 2.83 & 2.83 \\
K 6 g + G 25\% & 29.84 & 29.37 & 1.89 & 1.88 & 0.60 & 0.60 & 2.76 & 2.73 \\
K 6 g + G 50\% & 31.47 & 31.13 & 1.90 & 1.93 & 0.56 & 0.55 & 2.84 & 2.81 \\
K 6 g + G 100\% & 29.37 & 29.13 & 1.86 & 1.88 & 0.49 & 0.48 & 2.80 & 2.79 \\
\hline F test & $\star \star$ & $\star \star$ & $\star \star$ & $\star \star$ & $\star \star$ & $\star \star$ & $\star \star$ & ns \\
\hline LSD 0.05 & 2.01 & 1.41 & 0.03 & 0.03 & 0.02 & 0.02 & 0.03 & -- \\
\hline
\end{tabular}

Table (5): Effect of NPK fertilization and spraying garlic extract on some flowering parameters of Hedychium coronerium plants during 2017 and 2018 seasons

\begin{tabular}{|l|c|c|c|c|c|c|c|c|}
\hline \multirow{2}{*}{ Treatments } & \multicolumn{2}{|c|}{$\begin{array}{c}\text { Main stalk } \\
\text { length (cm) }\end{array}$} & \multicolumn{2}{c|}{$\begin{array}{c}\text { Main stalk } \\
\text { diameter (cm) }\end{array}$} & \multicolumn{2}{c|}{$\begin{array}{c}\text { Inflorescence } \\
\text { No./clump }\end{array}$} & \multicolumn{2}{c|}{$\begin{array}{c}\text { Rachis length } \\
\text { (cm) }\end{array}$} \\
\cline { 2 - 9 } & 2017 & 2018 & 2017 & 2018 & 2017 & 2018 & 2017 & 2018 \\
\hline Control & 68.67 & 70.33 & 1.13 & 1.12 & 4.67 & 5.67 & 5.00 & 4.33 \\
Kristalon 2 g & 70.67 & 73.00 & 1.14 & 1.13 & 6.00 & 8.67 & 5.33 & 4.67 \\
Kristalon 4 g & 79.33 & 86.00 & 1.15 & 1.15 & 8.33 & 10.33 & 7.67 & 7.00 \\
Kristalon 6 g & 82.50 & 83.33 & 1.17 & 1.14 & 8.25 & 11.00 & 8.00 & 6.33 \\
Garlic 25\% & 84.67 & 84.33 & 1.24 & 1.25 & 8.00 & 9.33 & 9.00 & 7.67 \\
Garlic 50\% & 89.67 & 92.33 & 1.22 & 1.25 & 9.67 & 11.67 & 10.00 & 9.33 \\
Garlic 100\% & 86.33 & 91.67 & 1.22 & 1.22 & 8.00 & 9.67 & 9.33 & 9.00 \\
K 2 g + G 25\% & 82.33 & 81.33 & 1.24 & 1.25 & 9.00 & 11.00 & 9.67 & 8.00 \\
K 2 g + G 50\% & 90.00 & 92.67 & 1.23 & 1.24 & 10.50 & 12.33 & 11.00 & 9.67 \\
K 2 g + G 100\% & 90.00 & 92.00 & 1.27 & 1.28 & 10.00 & 11.00 & 10.33 & 9.33 \\
K 4 g + G 25\% & 90.67 & 92.67 & 1.28 & 1.30 & 9.00 & 11.00 & 11.33 & 10.00 \\
K 4 g + G 50\% & 94.00 & 97.00 & 1.31 & 1.33 & 10.67 & 12.33 & 12.00 & 10.33 \\
K 4 g + G 100\% & 91.00 & 94.00 & 1.30 & 1.34 & 10.33 & 11.33 & 10.67 & 9.67 \\
K 6 g + G 25\% & 97.00 & 100.00 & 1.31 & 1.32 & 9.67 & 11.33 & 12.00 & 11.67 \\
K 6 g + G 50\% & 102.67 & 105.67 & 1.34 & 1.35 & 10.67 & 11.67 & 13.00 & 12.00 \\
K 6 g + G 100\% & 99.67 & 101.33 & 1.38 & 1.38 & 9.33 & 10.33 & 12.33 & 11.67 \\
\hline F test & $\star \star$ & $\star \star$ & $\star *$ & $\star *$ & $\star \star$ & $\star \star$ & $\star \star$ & $\star \star$ \\
\hline LSD 0.05 & 4.12 & 3.95 & 0.03 & 0.03 & 2.01 & 2.24 & 1.44 & 1.48 \\
\hline
\end{tabular}

Table (6): Effect of NPK fertilization and spraying garlic extract on some flowering parameters of Hedychium plants during 2017 and 2018 seasons

\begin{tabular}{|l|c|c|c|c|c|c|c|c|}
\hline \multirow{2}{*}{ Treatments } & \multicolumn{2}{|c|}{$\begin{array}{c}\text { Floret } \\
\text { No./inflorescence }\end{array}$} & \multicolumn{2}{c|}{$\begin{array}{c}\text { Flowering spike } \\
\text { fresh weight (g) }\end{array}$} & \multicolumn{2}{c|}{$\begin{array}{c}\text { Flowering } \\
\text { spike dry } \\
\text { weight (g) }\end{array}$} & \multicolumn{2}{c|}{$\begin{array}{c}\text { Vase life } \\
\text { (days) }\end{array}$} \\
\cline { 2 - 10 } & 2017 & 2018 & 2017 & 2018 & 2017 & 2018 & 2017 & 2018 \\
\hline Control & 5.67 & 6.00 & 116.30 & 115.17 & 10.23 & 9.65 & 5.33 & 4.67 \\
Kristalon 2 g & 8.33 & 6.67 & 119.71 & 119.73 & 11.57 & 11.63 & 5.67 & 5.33 \\
Kristalon 4 g & 9.67 & 7.67 & 125.73 & 123.00 & 12.34 & 12.93 & 7.00 & 7.00 \\
Kristalon 6 g & 11.00 & 9.00 & 124.25 & 120.83 & 12.00 & 11.91 & 7.50 & 7.33 \\
Garlic 25\% & 10.67 & 11.33 & 128.37 & 128.23 & 13.16 & 14.70 & 5.67 & 5.67 \\
Garlic 50\% & 10.67 & 9.33 & 127.67 & 121.60 & 12.94 & 13.06 & 5.33 & 4.67 \\
Garlic 100\% & 11.67 & 10.67 & 127.57 & 122.87 & 12.99 & 11.87 & 7.00 & 6.33 \\
K 2 g + G 25\% & 12.00 & 10.33 & 144.97 & 137.97 & 15.27 & 16.04 & 8.67 & 7.33 \\
K 2 g + G 50\% & 13.00 & 12.33 & 147.95 & 143.43 & 14.39 & 17.02 & 9.00 & 7.67 \\
K 2 g + G 100\% & 11.67 & 11.33 & 143.93 & 140.20 & 15.07 & 16.32 & 8.33 & 8.00 \\
K 4 g + G 25\% & 10.67 & 11.67 & 152.93 & 149.23 & 16.12 & 17.61 & 7.33 & 7.33 \\
\hline
\end{tabular}




\begin{tabular}{|l|c|c|c|c|c|c|c|c|}
\hline K 4 g + G 50\% & 12.67 & 13.33 & 159.30 & 157.43 & 17.90 & 18.74 & 9.00 & 9.33 \\
K 4 g + G 100\% & 11.67 & 12.67 & 156.00 & 154.63 & 17.01 & 17.25 & 8.67 & 9.33 \\
K 6 g + G 25\% & 11.33 & 13.67 & 161.70 & 159.70 & 18.22 & 17.91 & 8.33 & 10.00 \\
K 6 g + G 50\% & 13.67 & 14.67 & 167.23 & 165.67 & 19.43 & 19.12 & 10.33 & 10.67 \\
K 6 g + G 100\% & 13.33 & 12.33 & 162.63 & 160.30 & 19.33 & 19.12 & 10.00 & 10.00 \\
\hline F test & $\star \star$ & $\star \star$ & $\star \star$ & $\star \star$ & $\star \star$ & $\star \star$ & $\star \star$ & $\star \star$ \\
\hline LSD 0.05 & 2.13 & 2.23 & 4.61 & 4.51 & 1.63 & 1.02 & 1.40 & 1.38 \\
\hline
\end{tabular}

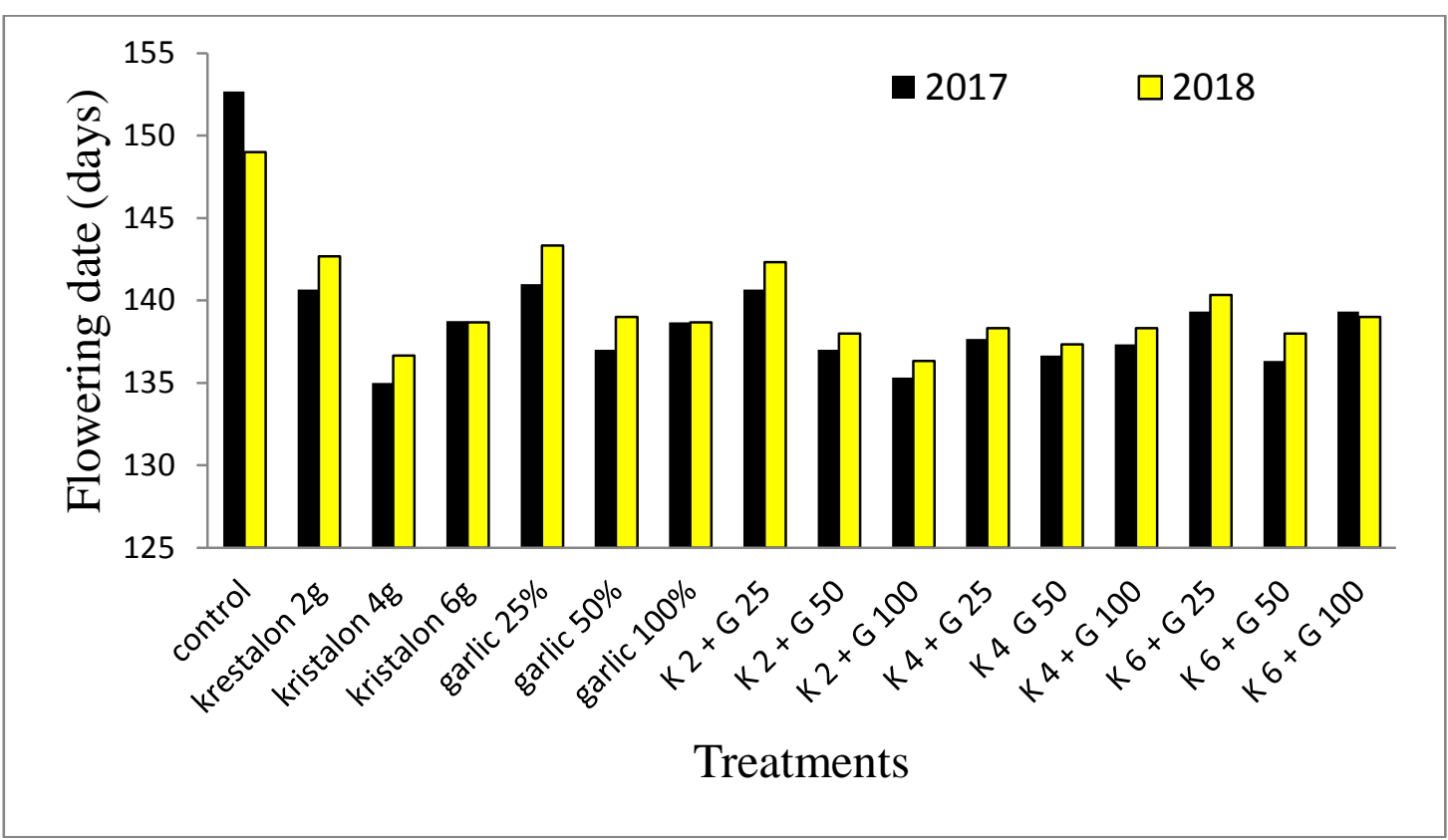

Figure (1): Effect of NPK fertilization and spraying garlic extract on flowering date (days) of Hedychium coronerium plants during 2017 and 2018 seasons

Whereas the flowering in the control treatments took the longest time to occur comparing with the other treatments in both seasons. Similar results were obtained by Bazaraa et al., (2012), Abdulrazzaq (2017) and El-Bably (2017).

Also, it is obvious from data presented in Tables $(5 \& 6)$ that, krestalon compound fertilizer of NPK (19:19:19) and spraying with garlic extract, alone or combined significantly increased main stalk length, main stalk diameter, inflorescence number/clump, rachis length, florets number/inflorescences, flowering spike fresh and dry weight and vase life plants compared to control treatment. NPK fertilizer and garlic extract as individual application increased all flowering parameters compared with control. It is also clear that spraying with garlic extract treatments was more effective in improve all flowering parameters compared to NPK fertilization treatments and control. The highest main stalk length, main stalk diameter, inflorescence number/clump, rachis length, floret number/ inflorescence, flowering spike fresh and dry weight and vase life were obtained from plants treated with 6 and $4 \mathrm{~g} / \mathrm{pot}$ NPK and sprayed with 50 and $100 \%$ garlic extract without significant different among themselves in both seasons. On the other hand, the lowest values of 
flowering parameters belonged to control treatment. These findings are in line with those obtained by El-Naggar (2010), Bazaraa et al., (2012), Hassan et al., (2015), Abdulrazzaq (2017), El-Bably (2017) and Abdou et al., (2018).

\section{REFERENCES}

Abd El-Gayed, M.E. and E.A. Attia (2018). Impact of growing media and compound fertilizer rates on growth and flowering of Cocks Comb (Celosia argentea) plants. J. Plant Production, Mansoura Univ., 9(11):895 - 900.

Abdou, M.A., A.A. El-Sayed, R.A. Taha, M.A. Abd-El Sayed and W.S. Botros (2017a). Effect of compost and some biostmulant treatments on guar plants. A-Vegetative growth and seed yield. Scientific J. Flowers \& Ornamental Plants, 4(1):143 - 157.

Abdou, M.A., A.A. El-Sayed, R.A. Taha, M.A. Abd-El Sayed and W.S. Botros (2017b). Effect of compost and some biostmulant treatments on guar plants. B- Chemical constituents and guaran productivity. Scientific J. Flowers \& Ornamental Plants, 4(1):143 - 157.

Abdou, M.A., F.S. Badran, E.T. Ahmed, R.A. Taha and M.A. Abdel-Mola (2018). Effect of compost and some natural stimulant treatments on: I. Vegetative growth and flowering aspects of Gladiolus grandiflorus cv. Peter Pears plants. Scientific J. Flowers \& Ornamental Plants, 5(2):105 - 114.

Abdulrazzaq, Z.M. (2017). Effect of garlic and licorice extracts on vegetative, root and floral trait of Gazania splendes L. J. Plant Production, Mansoura Univ., 8(10): 1055 - 1058.

Ahmad, A.K., K.A. Hammam and A.A. Amer (2014). Effect of bio-fertilization and some plant extracts on growth, yield and chemical constituents of basil plant. J. Plant Production,
Mansoura Univ., 5(2):193 - 210.

Al-Ajlouni, M.G., J.Y. Ayad and Y.A. Othman (2017). Increasing nutrient levels promote growth and flower quality in lilies grown under soilless culture. Hort. Sci. (Prague) 44(4): 171 177.

AL-Kaisy, W.A., R.W. Mahmood and E.H, AL-Hayani (2013). Effect of garlic (Allium sativum) extract and root extract of ginger (Zingiber officinale) on growth and yield of chick plant (Cicer arietinum). Baghdad Science Journal ,10 (4):1120 - 1125.

Altaee, A.H. and M.D. Alsawaf (2020). Effect of organic and chemical fertilizers on the growth and flowering of Freesia plant. Indian Journal of Ecology, 47(12): 275 - 280.

Ashokan, A. and V. Gowda (2018). Describing terminologies and discussing records: More discoveries of facultative vivipary in the genus Hedychium J. Koenig (Zingiberaceae) from Northeast India. PhytoKeys, 96:21 - 34 .

Atowa, D.I. (2012). Effect of growth media, organic and biofertilizers on growth and flowering of Freesia refracta cv. Red Lion. M.Sc. Thesis. Fac. Agric., Cairo Univ. Egypt.

Bashir, M., I. Khan, R.W.K. Qadri, M. Tanveer, M. Zain and I. Ahmad (2016). Growth and corm production of Gladiolus grandiflorus L. 'Essential' under different NPK regimes. Journal of Ornamental Plants, 6(1): 11 - 19.

Bazaraa, W.M., G.H. Abdel-Fattah and A. Nabih (2012). Response of Gladiolus cv. Novalux to some irrigation intervals, different levels of some biostimulants and their interaction on plant development, corms and cormlets production and chemical constituents of the new formed corms. Egyptian J. Hort., 39(2):121 - 147.

Brown, J.D. and O. Lillelland (1974). 
Rapid determination of potassium and sodium in plant material and soil extracts by flame photometer. Proc. Soc. Hort. Sci., 48: 341 - 346.

Chan, E.W. and S.K. Wong (2015). Phytochemistry and pharmacology of ornamental gingers, Hedychium coronarium and Alpinia purpurata: A review. Journal of Integrative Medicine 13(6):368 - 379.

Dahab, A.D., H.N. Nady and H.S. Abd EISalam (2018). The potential of some plants extract as bio-stimulants for enhancing growth and biochemical constituents of banana plantlets. Middle East Journal of Agriculture Research , 7(3): 904 - 914.

Dubois, M., A. Gilles, J.K. Hamiltom, P.A. Rebers and F. Smith (1956). Colorimetric method for determination of sugars and related substances. Analytical Chemistry, 28(3): 350 - 356.

El-Bably, S.M. (2017). Effect of some natural material additives on growth and flowering of tuberose (Polianthes tuberosa, L.) bulbs J. Plant Production, Mansoura Univ., 8(9):895 $-906$.

El-Desouky, S.A., A.L.A. Waneis and Z.M.A. Khedr (1998). Utilization of some natural plant extracts (garlic and yeast) as seed-soaked materials to squash (Cucurbita pepo, L.). 1. Effect on growth, sex expression and fruit yield and quality. Ann. Agric., Sci., Moshtohor, 36(2):839 - 854.

Elgohary, M.A., A.K. Dawh, A.S. Gendy and M.A. Abdelkader (2020). Response of caraway (Carium carvi, L.) growth and yield components to NPKMg fertilizer rate and antioxidants type. Zagazig J. Agric. Res., 47(4): 883 - 89.

El-Mahrouk, E.M., F.I. Radwan, A.I. Abido and A.H. Hammam (2016). Effect of some fertilization treatments on vegetative growth, oil production and chemical composition of sage plant. J.
Adv. Agric. Res. (Fac. Agric. Saba Basha) 21 (3):399 - 412.

El-Mokadem, H.E. and M. Sorour (2014). Effect of bio and chemical fertilizers on growth and flowering of Petunia hybrida plants. American Journal of Plant Physiology, 9: 68 - 77.

El-Naggar, A.H. (2010). Effect of biofertilizer, organic compost and mineral fertilizers on the growth, flowering and bulbs production of Narcissus tazetta, L. J. Agric. \& Env. Sci. Alex. Univ., Egypt , 9(1): 24 - 52.

El-Naggar, A.H. and A.B. El-Nasharty (2016). Effect of potassium fertilization on growth, flowering, corms production and chemical contents of Gladiolus hybrida, L. cv. "Rose Supreme". Alexandria Science Exchange Journal, 37(4):714 - 728.

EL-Sayed, A., Safia H. EL-Hanafy, A. Nabih and D.I. Atowa (2015). Response of growth, flowering, corms productivity and chemical constituents of Freesia refracta cv. Red Lion to some natural extracts. proc. $2^{\text {nd }}$ International Conference on Horticultural Crop, 15-18 March, Egypt.

Emam, O.N.K. (2010). Effect of treating tuberose plant (Polianthes tuberosa, L.) with some organic extracts to improve growth and flowering. Ph. D. Thesis, Fac. Agric., Ain Shams Univ., Egypt.

Evenhuis, B. and P.W. Dewaard (1980). Principles and Practices in Plant Analysis. FAO Soils Bull. 38:152 - 163.

Gaber, M.K. (2019). Vegetative and flowering growth of geranium as affected by mineral fertilization and ascorbic acid foliar application. Middle East Journal of Applied Sciences, 9(1): $220-230$.

Habib, A.M. (2012). Effect of NPK and growing media on growth and chemical composition of fishtail palm 
(Caryota mitis Lour). Life Sciences Journal, 9(4): 3159 - 3168.

Hanafy, M.S., F.M. Saadawy, S.M.N. Milad and R.M. Ali (2012). Effect of some natural extracts on growth and chemical constituents of Schefflera arboricola plants. Journal of Horticultural Science \& Ornamental Plants 4(1):26 - 33 .

Hassan, M.R., A.H. El-Naggar, E.H. Shaban and M.E. Mohamed (2015). Effect of NPK and bio-fertilizers rates on the vegetative growth and oil yield of Ocimum basillicum L. plants. Alexandria Science Exchange Journal , 36(1):58 - 72.

Massoud, H.Y., M.N. Sharaf-Eldin and A.M. Sheashaa (2017). Effect of biofertilizers, plants extracts and active dry yeast on marjoram plants. J. Plant Production, Mansoura Univ., 8 (5): 657 $-663$.

Murphy, J. and J.R. Riley (1962). A modified single solution method for the determination of phosphorus in natural water. Anal. Chem., Acta, 27: $31-38$.

Page, A.L., R.H. Miller and D.R. Keeney (1982). Methods of Soil Analysis part 2: Chemical and Microbiological
Properties Second Edition. Agronomy 920 Am. Soc. Agron. Inc. Soil Sci. Soc. Am. Inc. Pub. Madison, Wisconsin, USA.

Pregl, F. (1945). Quantitative Organic Microanalysis, $4^{\text {th }}$ Ed J.A. Churchill, Ltd, London.

Ruamrungsri, S., W. Bundithya, N. Potapohn, N. Ohtake, K. Sueyoshi and T. Ohyama (2011). Effect of NPK levels on growth and bulb quality of some geophytes in substrate culture. Acta Horticulturae 886:213 - 218.

Snedecor, G.W. and W.G. Cochran (1990). Statistical Methods. 7th E. lowa State Univ. Press. Ames., lowa, USA, pp. 593.

Youssef, A.S.M. (2014). Effect of different growing media and chemical fertilization on growth and chemical composition of ponytail palm (Beaucarnea recuvata) plant. Annals of Agric. Sci., Moshtohor , 52(1): 27 38.

Yue, Y., R. Yu and Y. Fan (2015). Transcriptome profiling provides new insights into the formation of floral scent in Hedychium coronarium. BMC Genomics 16(1): 470. Doi: 10.1186/s12864-015-1653-7. 
تأثير بعض معاملات التسميد ورش مستخلص الثوم على نمو و تزهير لتباتات الهيدكيم

إيمان علي أحمد عطية(')، صلاح عبدالعزيز جمعة(1) ، محمود عبدالنبي حجازي(؟)

(1) قسم نباتات الزينة و تنسيق الحدائق - معه بحوث البساتين - مركز البحوث الزراعية - الجيزة - مصر.

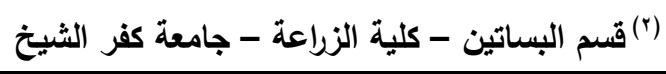
الملخص العربى

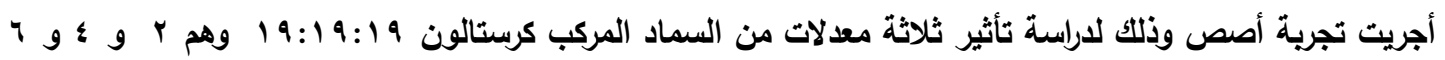

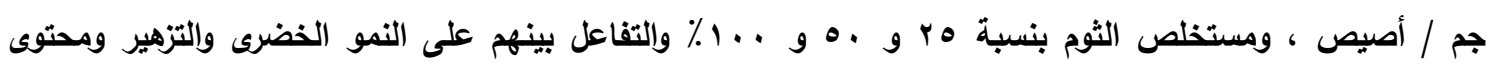

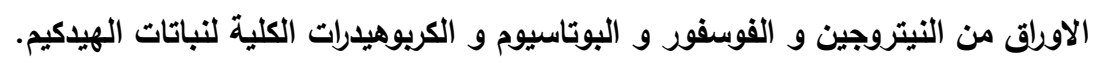

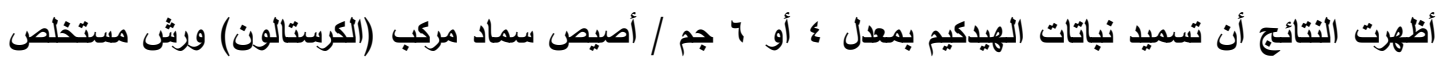

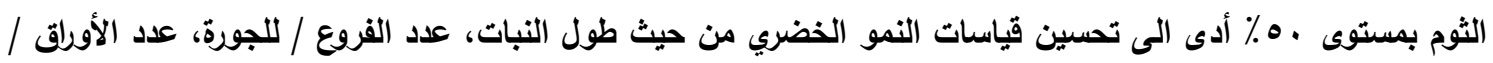

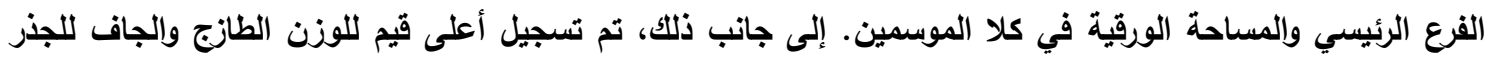

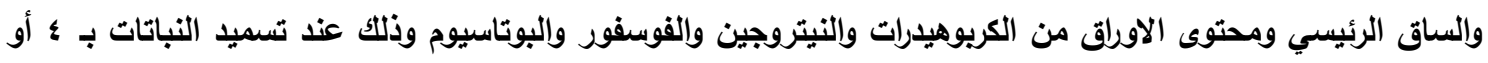

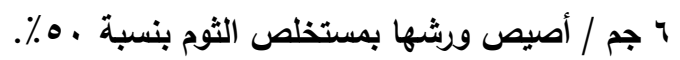

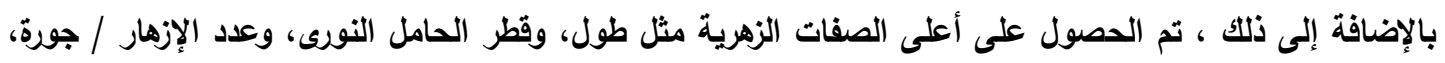

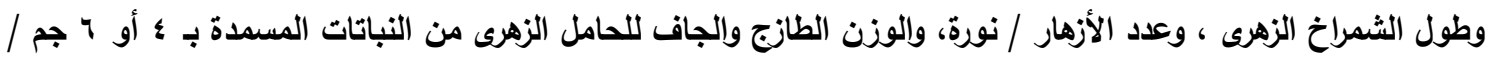

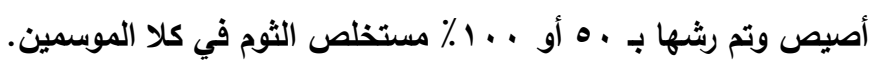
كما أعطت المعاملات السابقة أفضل و أطول عمر للازهار و أظهرت أنها فئها الأفضل في إحداث التزهير المبكر مقارنة بمعاملة الكنترول و المعاملات الأخرى.

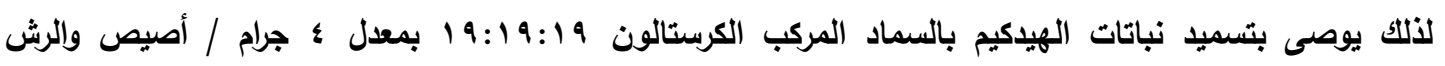
بمستخلص الثوم بنسبة ـ ـ وهى أفضل معاملة إقتصادية تستخدم لتحسين النمو والازهار و الحالة الغذائية للنباتات. 
السادة المحكمين

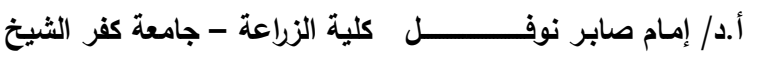

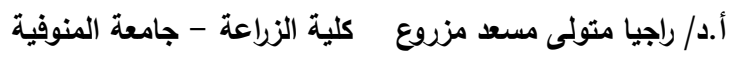

